
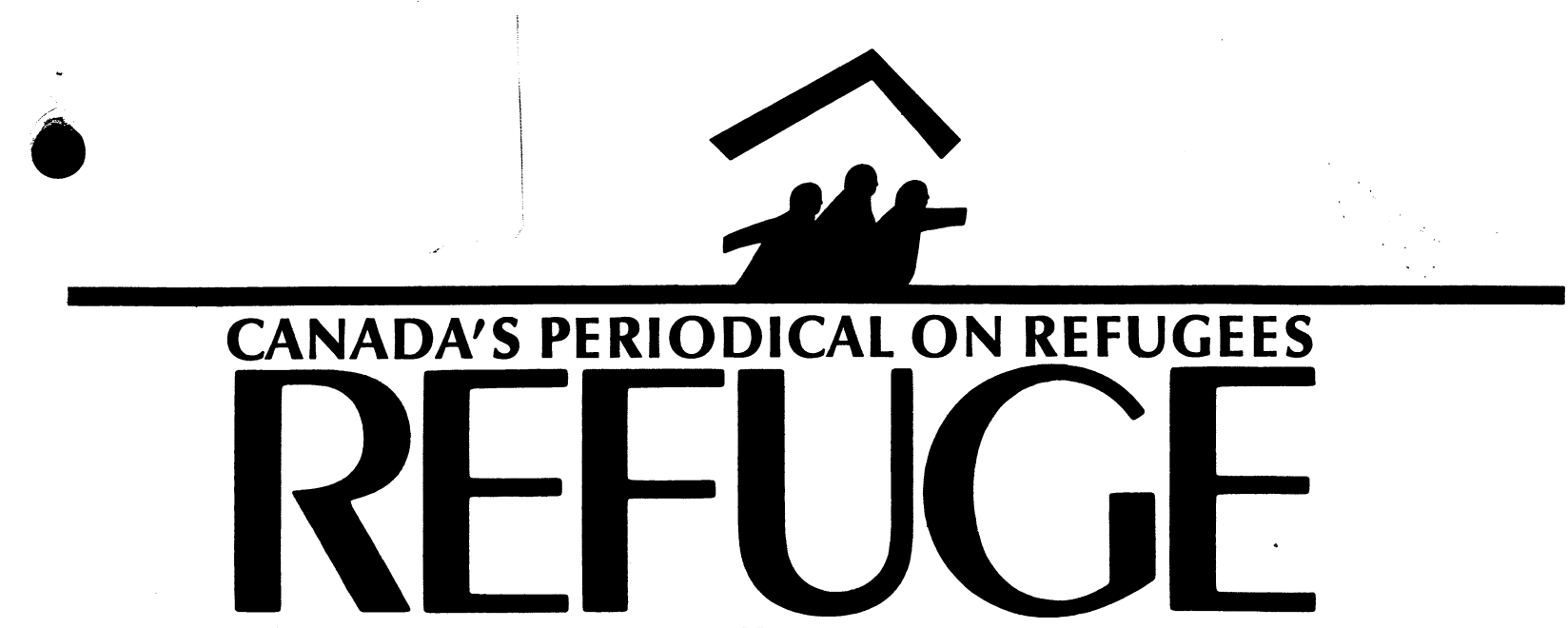

Vol. 3 No. 1

October 1983

\title{
The Insecurity of El Salvadorean Refugees
}

by Jeremy Adelman

A young girl burst into the schoolhouse frantically warning us that the "soldados" (soldiers) were entering the refugee camp. Elena, a Belgian teacher who coordinates the education program in one of the seven camps which constitute the larger camp of $E l$ Salvadorean refugees called Mesa Grande, rushed to the door. Rapid instructions on the afternoon's classes were given to the teachers who were meeting with her. Hurrying through the maze of ramshackle buildings and fields, Elena explained that this was not an uncommon experience. Honduran troops (as the defense forces of the host country of these refugees) enter periodically into the camps. Haste was needed to minimize the chaos and paralysis of all work and activity which inevitably follow the sighting of the battalion.

From the sight where most of the schools were concentrated, six soldiers could be seen half a kilometre away, entering the camp after climbing the steep hill which surrounds the plateau of Mesa Grande. The children, having fled the classroom at the news of the ap- proach of the soldiers, were scattered in the fields, observing from a distance the movement of the troops. In an attempt to restore order, Elena encouraged the teachers to resume classes and treat the incident as a regular event that should not disturb essential activities. Elena then turned to the kids who, after being called, slowly made their way back to class in time to finish the last ten minutes of school.

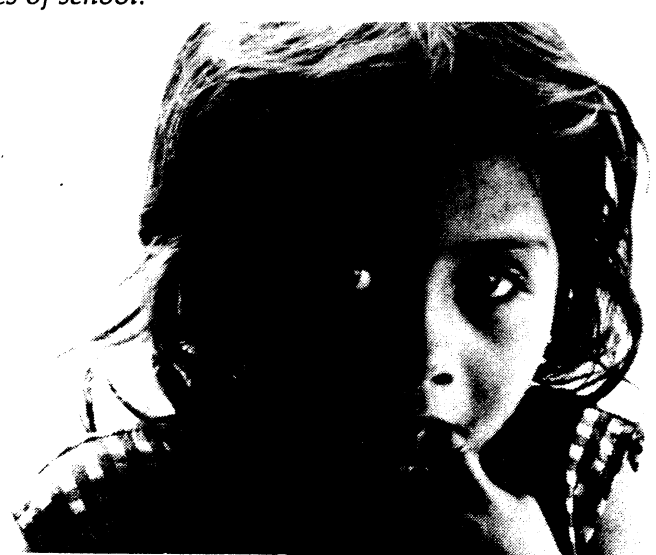

Refugee child in Camp Colomoncagua.
Meanwhile, the soldiers continued to meander through the camp, waving their rifles or sticks at the refugees. The Salvadoreans had ceased whatever they were doing to watch with trepidation and fear, despite the frequency of military visits, as the soldiers (who to the refugees were indistinguishable from those they had fled back home) passed by.

(Continued on p. 3) 
El Salvadorean Refugees

(cont'd from p. 1)

Elena, like many others who work to organize and maintain crucial activities, fights a rear-guard battle against the destabilizing actions of the military. Moreover, a pervasive sense of uncertainty and insecurity exists beyond regular military incursions, which the United Nations High Commissioner for Refugees (UNHCR) seems incapable of dealing with in an effective manner. This generic sense of insecurity undermines broad efforts to provide an interim "home" to displaced Salvadoreans in all the camps, of which Mesa Grande is the largest in Honduras.

There are four dimensions to the insecurity which prevails in the camps. First, uncertainties arise from forces outside the camps' boundaries, such as military incursions. Second, internal factors, (such as petty crimes and jealousies) generic to any society, are exacerbated by the tensions of a concentrated refugee camp experience. The third and fourth dimensions involve insecurities about the past and future. Both contribute to a present sense of unease. The past experience of violent upheavals from traditional lifestyles and values back home and placement into circumstances (camps) alien to the Salvadoreans create an environment of uncertainty. The uncertainty of the future is caused partly by the unpredicatable nature of events within El Salvador (determining whether or not the refugees can return home) and partly by the UNHCR's general policy of "reubicación" (camp resettlement) to which the refugees are emphatically opposed.

The UNHCR cannot rectify uncertainties related to the violent experience of the past. Nor can it do much about internal "social" tensions, though the UNHCR does foster internal management of civil order by the refugees themselves, and, in the case of violations, depends on the Honduran law enforcement agencies and judicial system.

The UNHCR can play a critical role in relation to the problem of external uncertainties and future camp policy. In both areas the UNHCR has experienced some successes and some failures. The extent to which the UNHCR can prove effective in these realms is conditioned by the local structure within which the UNHCR finds itself.

The UNHCR provides protection to refugees and seeks "durable solutions to their problems". The discharging of these responsibilities is done through national or local authorities (such as the erstwhile Honduran Refugee Commission - CEDEN), and/or through other $\mathrm{UN}$ and international agencies (OXFAM, Catholic Relief Services, Médecins sans Frontières, etc.). UN guidelines stipulate "a formal link between UNHCR and the national authority responsible for the protection of refugees". The aim is to unite the UNHCR with appropriate national bodies in a cooperative discharging of the duties of the UNHCR.

Honduras is neither a signatory to the Convention nor to the Protocol; nor does it have a national agency charged with cooperating with the UNHCR.



The implications of this are twofold: (1) the UNHCR has no collegial affiliate to discharge its basic functions even though it has the support of international and foreign agencies, and (2) Honduran authorities are not bound by international stipulations on refugee "status" or "treatment". The first implication creates a higher degree of burden than is desired by the UNHCR. The second has profound ramifications on the ability of the UNHCR to use the international legal infrastructure in support of its policies.

Simply put, the abstention of Honduras from the attendant clauses of international law referring to refugees gives local and national authorities arbitrary powers - accountable only to local or national law. The effectiveness of the UNHCR in providing security within the two main spheres of external (political) factors and future policy towards the camps is ham-strung by the limitations imposed by local authorities. To preserve its already beleaguered relationship with the authorities, the UNHCR systematically chooses not to react strongly in the event of infractions. Also, given its negative image in Honduras, the UNHCR tries to mollify tensions with the authorities by relinquishing its responsibility to preserve security for refugees and those dealing with them.

In the realm of external (political) factors, this is manifest in several ways. Constant insecurity is created by military incursions. Recently, the military imposed an embargo on all building supplies indefinitely. Further, Honduran workers paid to provide services driving lorries, teaching or basic engineering are subject to fear of harrassment by the military. One Honduran fumigator working with a Canadian nutritionist in Camp Colamoncagua was picked up by the military for allegedly not having his identification papers in order. The UNHCR, in order not to jeopardize its tenuous link with the authorities, exerted little pressure on the military and left the Canadian nutritionist to arrange the release. The coordinator of workshops (hired by Catholic Relief Services) in one of the camps spoke candidly of his fear of arbitrary arrest.

In the daily, La Prensa, on June 23, 1983, the UNHCR was accused of harbouring guerrillas in Mesa Grande who conducted regular raids into nearby

(Continued on p. 4) 


\section{El Salvadorean Refugees}

(cont'd from $p$. 3)

towns. UNHCR coordinators Maria Carmen Aubanell (Mesa Grande) and Mercedes Aubanell (Colamoncagua) were named "principal suspects". Other international workers were accused of having links with the Palestinian Liberation Organization and disseminating "Marxist literature" amongst the refugees.

The multitude of external factors which contribute to the general unease, compounded by the arbitrary legal ties which characterize the relationship between Honduran authorities and the UNHCR, severely limits the UNHCR's ability to provide the refugees with a sense of security.

Problems of insecurity are worsened by the policy the UNHCR has adopted visà-vis the future of the camps. In this case, the UNCHR cites the danger posed by the camps' proximity to the border between Honduras and El Salvador as reason for resettlement of the camps. The possibility of incursions by the Salvadorean military or agents of ORDEN (ultra-rightist terrorist organization) does exist - particularly at camps Colamoncagua and San Antonio which are within earshot of $\mathrm{El}$ Salvador. Such incursions did occur in the now-defunct camps of La Virtud and San Juan de Guarita. The response then was to erect a new camp, now Mesa Grande, further inland and move the refugees out of the border region. The move also sought to derail accusations of guerrilla affiliation with the refugees.

The establishment of Mesa Grande has insulated the refugees from death squads and the Salvadorean army. But accusations of guerrilla ties, as exemplified by the article in La Prensa, still abound. Moreover, the actions of the Honduran military continue unabated, allowing fear and uncertainty to persist despite resettlement.

The resettlement policy is further confused by the apparent schism between local authorities who are content to leave Mesa Grande intact and the UNHCR who adamantly maintains its policy of resettlement. The authorities would seek the resettlement of other camps, but would prevent implimentation of durable solutions by denying access to lands, markets and work. The UNHCR forsees the disbanding of Mesa Grande and its re-establishment elsewhere as a move towards a more durable solution. When pressed on the incongruity with government policies, the UNHCR spokesman simply refers to "negotiation" as the means to finding an agreement.

Much energy and resources have contributed to the construction of the camps and the development of a feeling of a "temporary home". None of the refugees spoken to would like to move. All expressed weariness at constant shifting and mobility, and pointed to their struggle to recreate from scratch within the camps the semblance of a life they led in El Salvador. To begin now to uproot the refugees once again, without their consent, would be tantamount to undoing all that has so far been achieved.

Resettlement in an appropriate area would go a long way to establishing a "durable solution" by giving refugees access to local markets and labour mobility. But as it stands, the most seriously considered region is the province of Olancho - where hundreds of thousands of migrant Salvadorean workers were persecuted and subsequently evicted during the "Soccer War" of 1969 and where memories of that period still linger amongst some of the refugees. Recent documentation of extensive human rights violations (including the abduction and murder of a French-Canadian priest) and the barbarism of local authorities belie the humanitarian intent of this serious proposal.

Moreover, the establishment of an American military training base for thousands of Salvadorean soldiers in nearby Puerto Castilla makes the possibility of resettlement to Olancho, not of genuine interest in the welfare of the refugees, but a policy designed with larger geo-political permutations.

The UNHCR's adoption of such a policy; (1) exacerbates the current feeling of uncertainty on the part of the refugees and (2) puts into serious question the ability of the UNHCR to operate effectively under the weight of arbitrary legal structures. Fear of Honduran military reprisals and bureaucratic belligerence has made the UNHCR compromise on its dual function of protection and provision of durable solutions. The persistence of external uncertainties which are only partially resolved, the unpredictability of the future (whether or not resettlement will occur) are in part caused by the UNCHR's structural dilemma. This dilemma is in turn caused by the nature of Honduras' general refugee policy.

Despite the UNHCR's commendable record in providing services, supplies, and material requirements to Salvadorean refugees, it falls short on the more complex problem of providing a secure environment in which the refugees can take a brief respite from the tensions of war which surround them.

Jeremy Adelman was one of the founders of Operation Lifeline and spent this past summer in Central American refugee camps.

\section{Canada Accepts 134 Freed Salvadorean Political Prisoners}

The Constituents Assembly in El Salvador declared, on May 5 this year, a 60-day amnesty (Ley de Amnistia y Rehabilitación Cuidadan) for political prisoners, guerillas and exiles who wished to either reintegrate into $E l$ Salvadorean society or to resettle in a new country. During the amnesty period, El Salvador released approximately 550 out of a possible 730 prisoners.

As a result of the amnesty, Canada has admitted 134 freed Salvadorean political prisoners. With them came 139 family members. They have been admitted to Canada under the authority of the Oppressed Persons and Political Prisoners Program.

When the amnesty was declared, the Canadian government sent a team of external affairs officers who had experience in Latin America to San Salvador. The El Salvadorean government allowed the Canadians to examine and identify political detainees released under the amnesty program. Canada was prepared to accept for resettlement prisoners who had been detained for legitimate, non-violent political activity.

All the prisoners admitted to Canada were government sponsored. Most have been resettled in either Quebec or Ontario because of available financial assistance and the existence of community support groups. Many are now living in smaller cities such as London, Ottawa, Kitchener, Hull, Quebec City and Sherbrooke. 